\title{
Sustainability of Economy: Inflation vs Interest Rates
}

\author{
Rohitha Goonatilake \\ Orlando D. Reyes \\ Department of Mathematics and Physics \\ Texas A\&M International University \\ 5201 University Boulevard \\ Laredo, Texas 78041-1900 \\ USA
}

\begin{abstract}
An economy is said to be sustainable when there is harmony between various economic factors, including inflation and interest rates as they play a pivotal role in the economic affairs of a nation. Inflation determines the extent of borrowing power among its people. If consumers have more money, they can spend, causing the economy to grow and inflation to subdue. Inflation and interest rates are closely related to each other and are frequently referenced together in economics literature. This paper sheds light on this relationship together with its effects on various economic factors associated with a market economy. The purpose of this paper is to discuss and elaborate on some of the consequences that provide uncertainties throughout the world, which are causing inflation to rise. Inflation can be effected by other economic phenomenon such as unemployment, globalization, outsourcing, migration, and terrorism. The effects of them are also revisited. Finally, the significance of association between the relationship of inflation and interest rates is statistically justified.
\end{abstract}

Keywords: Inflation, Interest rates, Phillips Curve, Fisher Equation Globalization, and Unemployment

\section{Preliminaries}

The sustainability of growth of a nation's economy is characterized by a rate of growth that can be maintained without creating some other significant economic difficulties for its people, especially for their future generations. Many economic factors influence the sustainability of economic conditions of a country. Inflation and interest rates are just a couple of them. Whereas inflation seems to occur naturally, the federal government uses interest rates as a way to curb inflation. Furthermore, it has been statistically shown that the gross domestic product (GDP) is a linear function of unemployment and inflation. Evidently, the inflation is a factor of GDP, one of the most important indications of the national economic development of a nation (Espinoza, Goonatilake, \& Herath, 2018). The economic definition of inflation can vary. For the purpose of this paper, inflation is defined as a general increase in the prices of goods and services in a country, commonly measured as the annual rate of change of the Consumer Price Index (CPI), which is measured by the percentage change in the price of a quantity of goods and services consumed by households. As for interest rate, at any given point in time, there are a vast array of rates, that are prevalent under the market conditions. These rates are used in the myriad of financial transactions involving them: prime rates, federal funds rate, and discount rate. These three seemingly share a simple relationship with one another. However, they must be carefully monitored so as to not cause a disturbance in the economy of the country. The federal funds rate is set based directly on how the economy is doing and where it appears to be trending towards. The adjustment of interest rates is the role that the government plays in attempting to keep inflation at a constant rate, to offset any negative "real" interest rates. If inflation is predicted to increase, then the federal funds rate will increase as well, so as to discourage a lot of lending. On the other hand, in a harsh economic situation, the federal funds rate will be really low, to encourage lending and growth in the economy. The federal funds rate will in turn influence the prime rate, as the prime rate is loosely based on the federal funds rate. Essentially, a high federal funds rate will lead to a high prime rate. Although the discount rate is a relationship only between the Federal Reserve and other banks, it has implications that affect the economy at large. Since the discount rate has to be higher than the federal funds rate, it is effectively the 'target' or 'cap' of the federal funds rate. The changes in the discount rate reflect significant monetary policy by the Federal Reserve Board that will in turn have a widespread effect throughout the economy. Peter Ireland says that their strategy lies in controlling shortterm nominal interest rates, which in turn controls inflation. From the contracted real interest rate, we could be able to determine the expected inflation rate using the Fisher Equation, $i=r+\tau^{e}$, where $\tau^{e}$ is the expected rate of inflation, $r$ is the contracted real interest rate and $i$ is the nominal interest rate. 
The nominal interest rates are publishable and as such, they are observable (Crowder \& Hoffman, 1996). Ireland also claims that the controlling of short-term interest rates helps control inflation because controlling those interest rates offsets "shocks" to the economy that would inevitably raise inflation (Ireland, 2000).

For the US population, who had become accustomed to uninterrupted economic progress since the 1930s, the decade of the 1970s was a turbulent one. Policies and prevailed economic woes of the decade were a failure of income, many families faced to keep up with inflation. Many pointed out a variety of possibilities for this "shock", such as inflation, government deficits, higher energy process, rising taxes, reduced national saving and investment, increased government regulation, and others. The factors associated with the theories of microeconomics interact to determine the real interest rate and rate of return; during the inflationary periods, the nominal rate will exceed the real rate by the rate of inflation. A deficit occurs when the government spends more than it receives in tax revenue. The excess of spending over revenue could be financed by printing money, but this option is likely to cause inflation (Browning \& Browning, 1986).

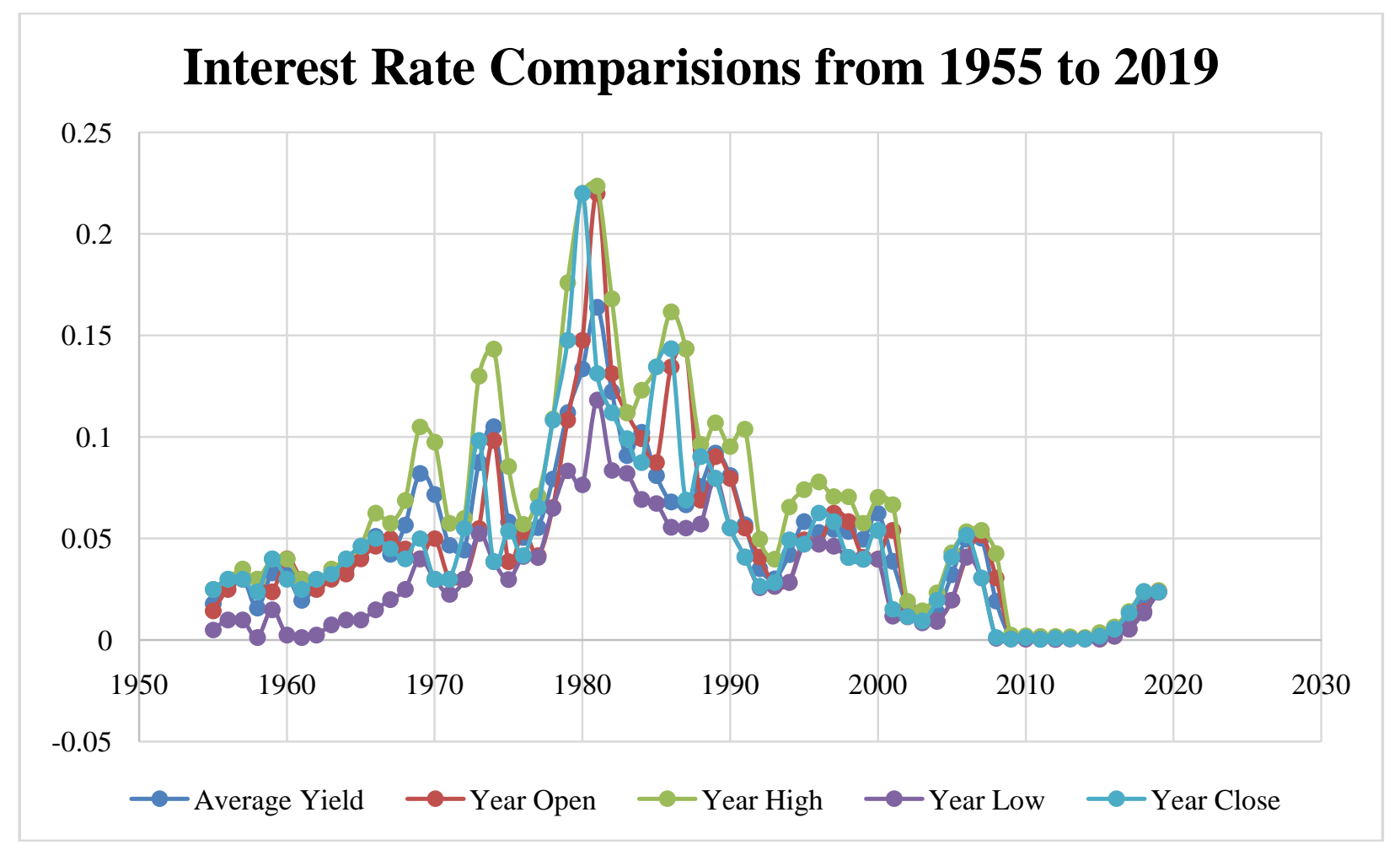

Figure 1. Plots of average yield, year open, year high, year low, and year close from 1955 to 2019

From the data in Figure 1, it can be concluded that as for the Federal Funds Rate - Historical Annual Yield Data, choosing any of the interest rates for the data for analysis would be appropriate since the data share a close proximity with one another we would observe similar results. A collection of the Year Close Fed Interest Rate and Inflation from 1955 to 2018 has been analyzed to investigate the effect of interest rates on inflation which provided the same insight. Figure 2 shows that the Year Close Fed Interest Rate and Inflation from 1955 to 2018 share similar characteristics, which implies there must be some influence on one another. It can be argued that if the economy shifts abruptly from zero inflation to a uniform annual inflation rate of $1 \%$, nominal sales will rise and consequently, the real sustainable growth rate is independent of the inflation rate, adding to this a profit that leaves economic outlook unchanged (Higgins, 1981).During the $20^{\text {th }}$ century, two economists, Fisher and Darby, proposed conflicting ideas on the relationship between nominal interest rates, inflation, and "real" interest rates. It is neither the Fisher nor the Darby hypotheses, which are correct in their estimation of "real" interest rates concerning anticipated inflation (Levi \& Makin, 1978). Unlike previous articles, which try to argue one over the other, Levi and Makin concluded that neither prevailed over the other, and instead the theories should be married into a set to create a comprehensive macro-economic model. Their concluding remark was simply that both Fisher and Darby were attempting to measure a coefficient that "varies randomly over time". Establishing some of the causes of inflation include the demand and supply side of the economy that causes both, the demand-pull and cost push inflation (Khumalo, Mutambara,\& Assensoh-Kodua, 2017). Since inflation is affected by a wide variety of factors, some that are entirely unforeseeable, it stands to reason. 


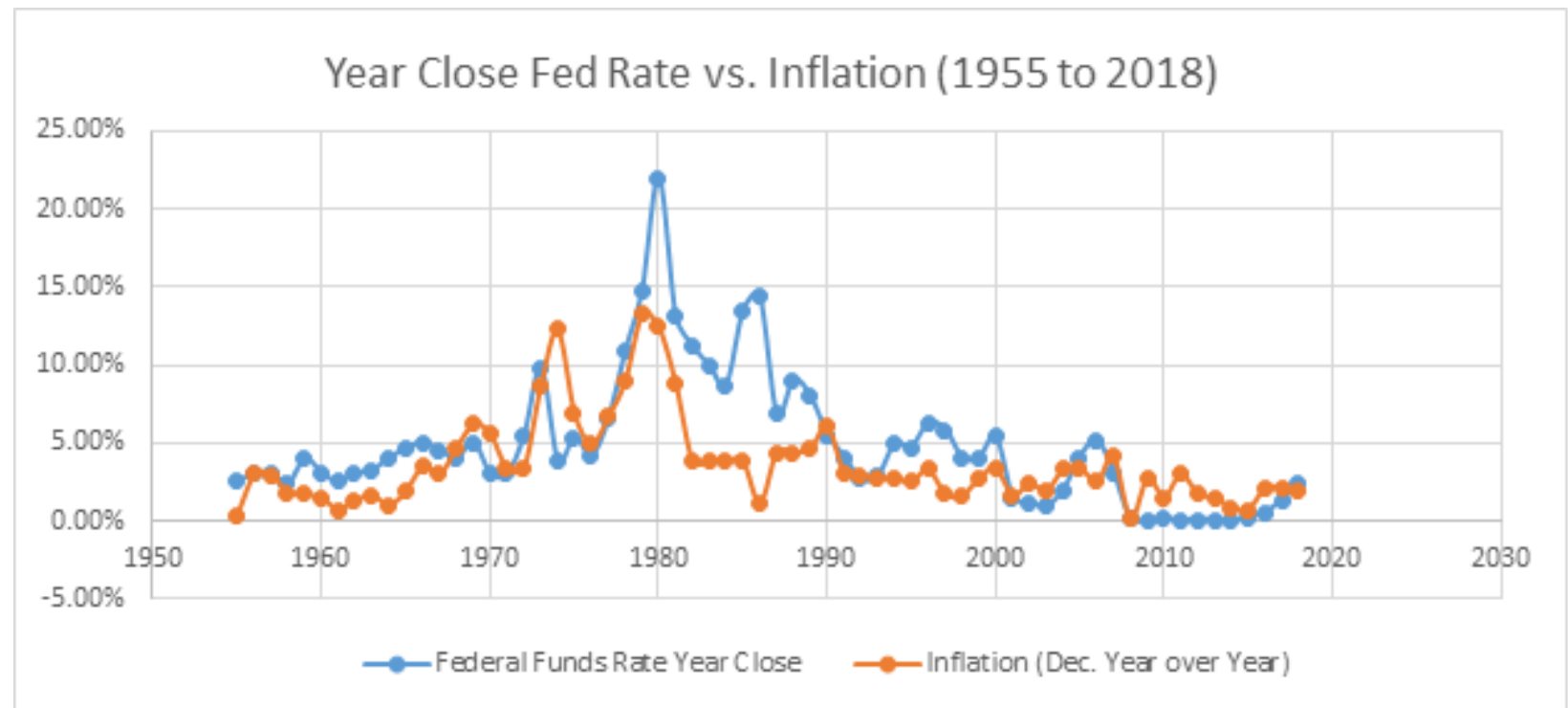

Figure 2. Comparison of year close fed interest rates and inflations from 1955 to 2018

In spite of taxation, Fisher's ideas are possible, as Feldstein claims it is impossible, due to the empirical evidence of Fisher's claims being attributed to "the depressing influence that historic-cost depreciation rules have had in the face of inflation". This depressing influence is the reason why taxation seems to play no role in the "real" interest rate; Gandolfi states that since "capital gains are taxed when realized and not as they accrue", tax on capital gains will undoubtedly be lower than tax on real income, thus the "Fisher" effect is observed. Crowder and Hoffman (1996) revisit the conventional "Fisher" equation and try to find the reason for its empirical success, in spite of its lack of taking taxation into consideration (Crowder \& Hoffman, 1996). The first pages of their article detail what economists after Fisher have argued, whether against or for him. Unlike others who attempt to replace this equation, these authors support the idea of a "tax-adjusted" Fisher equation. Their claim is that the relation between inflation and nominal interest rates causes only an insignificant difference from the conventional Fisher relation. A method is devised to calculate "real" interest rates based on forecasts rather than empirical evidence. Kandel et al. (1996) uses Israel as a basis for their data, since their government issues nominal bonds. Through their research, they found that the Fisher hypothesis is inconsistent when looked at through ex-ante analysis, while the theories of economists after Fisher appear to be consistent. A brief summary of the counter-argument to the "Fisher" effect, which is the "Darby" effect, states that, all other things remaining the same, interest rates during a period of inflation will rise to an amount that exceeds the expected inflation, for the purpose of preventing capital loss to lenders, as well as mitigating any taxation. Ayanian (1983) claims that previous economists have failed to validate the Darby effect due to the difficulty of measuring aftertax real interest rates and expected inflation rates. However, similarly to Kandel et al., by looking at nominal bonds, Ayanian was able to validate the Darby effect.

\section{Mathematics of Inflation}

Another factor associated with the level of interest is the length of the investment period. At a given point short-term and the long-term rates of interest are different, called the term structure of interest rates and displayed in the yield curve. Several theories have been advanced in attempting to explain why the upward trend seen in the yield curve typically develops in the market. The inflation recurrence theory states that the investors feel a significant amount of uncertainty about future rates of inflation and as such demand higher rates of interest on longer-term investments as higher rates of inflation lead to higher rates of interest to dampen the market values of investments. Fiscal policy is sustainable as long as the government's solvency conditions are fulfilled (Hauner\& Manmohan, 2006). The solvency condition requires the equalization of the net present value of primary surpluses and debt obligations it has to the outside agencies (Ley, 2009). In the end, what determines the size of government intervention are the views on the public sector's role in the economy. In addition, there are the constraints imposed by the sustainability of the current inflation that account deficit including the external borrowing, existing targets for inflation and output growth, and sustainable internal debt limits (Van Wijnbergen, 1990). Studying similar problems in the Turkish economy is an interesting case. The government in Turkey was able to establish monetary policies and stabilize a successful decrease in their inflation and interest rates. This case can help in analyzing to what extent an independent study can be successful. Secondly, fiscal policy should be sustainable and in line with monetary policy for the sustainability of fiscal deficits (Özatay, 1997). 
A sustainable debt-deficit combination paired with level of spending should be stable in terms of the debt-GDP ratio as well as fiscal deficit to GDP ratio, while being consistent with the permissible levels of primary expenditures. The short rates depend in this scenario amounts to full employment exchange economy on the current level of debt (Blanchard, 1984). Cochrane and Piazzesi (2002) looked at the role the Federal Reserve plays in regard to monetary-policy shocks, and how they target monetary policy as a reaction to interest rates, to prevent catastrophes in the economy. They studied it by a method of "high-frequency" which means that they collected daily data and then extrapolated it into monthly data to look for patterns, which might support their claims. Their idea is that when there is a "natural" shock to the economy, the Federal Reserve Board of Governors in Washington DC will in turn react with a monetary policy shock of its own.

\section{Relationship to Interest Rates and Unemployment}

An in-depth exploration into what is called the "real" rate of interest has been well studied (Leuthold, 1981). The real rate of interest, as described by Leuthold is "arrived at by subtracting the inflation rate from the quoted (nominal) interest rate". With the acceptance of this "real" rate, Leuthold has shown a meaningful relationship between interest rates and inflation. Namely, that an interest rate must be greater than inflation in order for there to be a positive "real" rate. There is considerable evidence to conclude that rates of interest are positively correlated with rates of inflation. Rate of interest eliminating inflation is often called the real rate of interest and is denoted by $i$, the actual rate of interest in the market is often called the nominal rate of interest $i$, if the rate of inflation is $r$, we have $1+i=\left(1+i^{\prime}\right)(1+r)$, where $r>0$ and $i>i^{\prime}>0$, assuming the rate of inflation is positive. This leads to $i^{\prime}=\frac{i-r}{1-r}$. According to the theory, $i$ is relatively stable over time. In an effect to calculate the present value of a series of payments at the end of each period for $n$ periods in which the base payment amount at time, $t=0$, is $R \cdot R\left[\frac{1+r}{1+i}+\frac{(1+r)^{2}}{(1+i)^{2}}+\frac{(1+r)^{3}}{(1+i)^{3}}+\cdots+\frac{(1+r)^{n}}{(1+i)^{n}}\right]=R(1+$ r) $\frac{1-\left[\frac{1+r}{1+i}\right]^{n}}{i-r}$, representing the present value of the payments including inflation computed at the nominal rate of interest. Using $1+i^{\prime}=\frac{1+i}{1+r}$, we have $R\left[\frac{1}{1+i^{\prime}}+\frac{1}{\left(1+i^{\prime}\right)^{2}}+\frac{1}{\left(1+i^{i}\right)^{3}}+\cdots+\frac{1}{\left(1+i^{\prime}\right)^{n}}\right]=R a_{\bar{n} \mid i^{\prime}}$. The value of the investment in "normal dollars" at the end of $n$ periods is $A(1+i)^{n}$. If the rate of inflation is $r$, then the purchasing power of the investment at the end of $n$ period is $A \frac{(1+i)^{n}}{(1+r)^{n}}=A\left(1+i^{\prime}\right)^{n}$, in which an investor invests an amount of $A$ for $n$ periods at an interest rate $i$ (Kellison, 1991). Therefore, a sustainable economy will be one, which has positive "real" interest rates and a positive return on the investment.

The sustainability of the current growth process in Argentina has been analyzed, taking into account the macroeconomic consistency and environmental constraints. It appears to be generating an unsustainable current account deficit and a relative price distortion in favor of non-tradable, impeding a much-needed increase in exports. Resolution of its main environmental problems would absorb savings slightly over the next 10 years. The saving insufficiency suggests that a gradualist policy giving priority to the urban environment should have been employed (Chisari, Fanelli, \& Frenkel, 1996). It conducted an analysis pertaining to the sustainability of fiscal deficits in Turkey whereby they seek levels of "financeable deficit", which are compatible with sustainable internal growth and noting that in a steady-state growing economy, budget deficit, inflation and debt sustainability can occur (Akgay, Alper, \&Ozmucur, 2018). The Phillips curve characterizes the association between the rate of inflation and the unemployment rate. In support with the long-run Phillips curve, in the end, monetary policy influences both the inflation rate and as a result, the unemployment rate inversely.

We can be certain that there is a concrete relationship between inflation and interest rates. However, the relative strength of the relationship will vary in different countries, and will be affected by different factors. Levine (1981) lists four reasons that lead to a weakness in the relationship between inflation and interest rates, as they pertain to the stock market. The reasons he lists are: loss of diversification, loss of liquidity, carrying costs, and loss of leisure time. The first deals with people whose investments will not be diversified, as they will shy away from investing in commodities to avoid the "slightly negative real return over time." The second deals with the inability to liquefy certain very valuable goods. The third posits that the cost of maintaining certain commodities might offset their values that in turn causes the weakness in the relationship. The final reason simply says that people are not willing to lose leisure time in order to learn enough about the market. He claims, "[t]his probably is the principal reason [for] the weakness of the inflation-interest rate relationship." However, that implies that if everyone learned about the marketplace, then there would be a stronger relationship between the two. Since there are too many factors working in unison, one cannot assume that people focusing on learning about the market will lead to a stronger or more sustainable economy. 


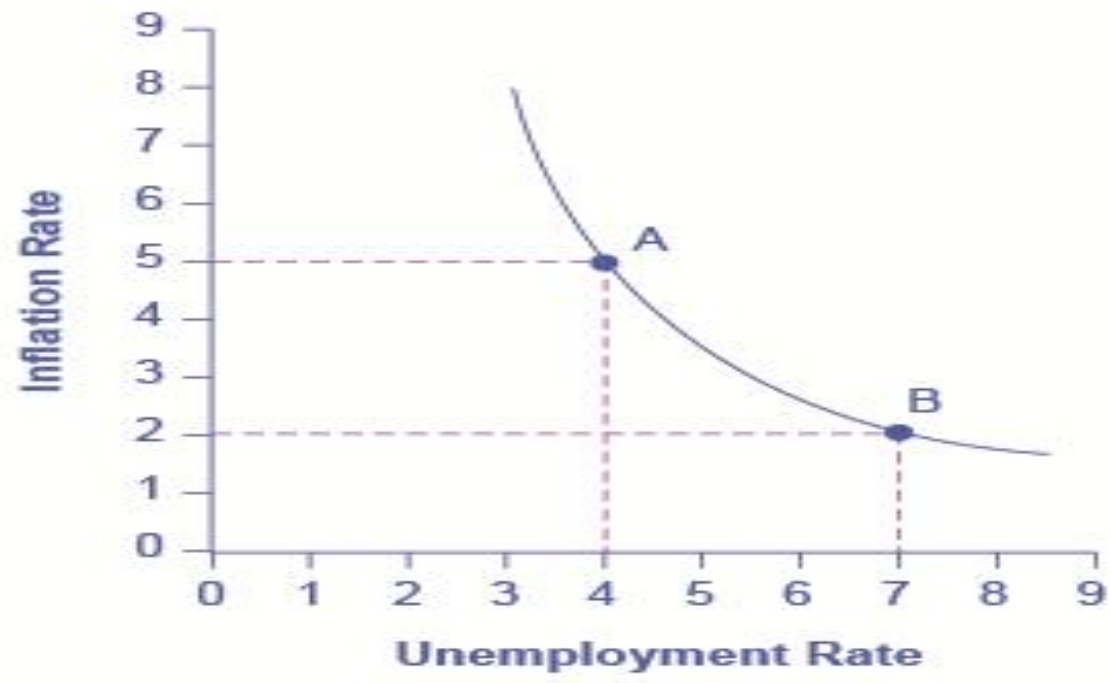

Figure 3. Phillips curve characterizes the association between inflation and unemployment

The Phillips curve illustrates that there seems to be an inverse relationship between unemployment and inflation in the short run, but not the long run as supported by the data of the US economy as provided in Figure 3. This helps to illustrate the purpose that that the government plays in keeping inflation at a balance. If inflation skyrockets, people will not be able to afford products or services, which will weaken the economy. If inflation is too low, as the Phillips curve suggests, unemployment will be the cause of hurting the economy.

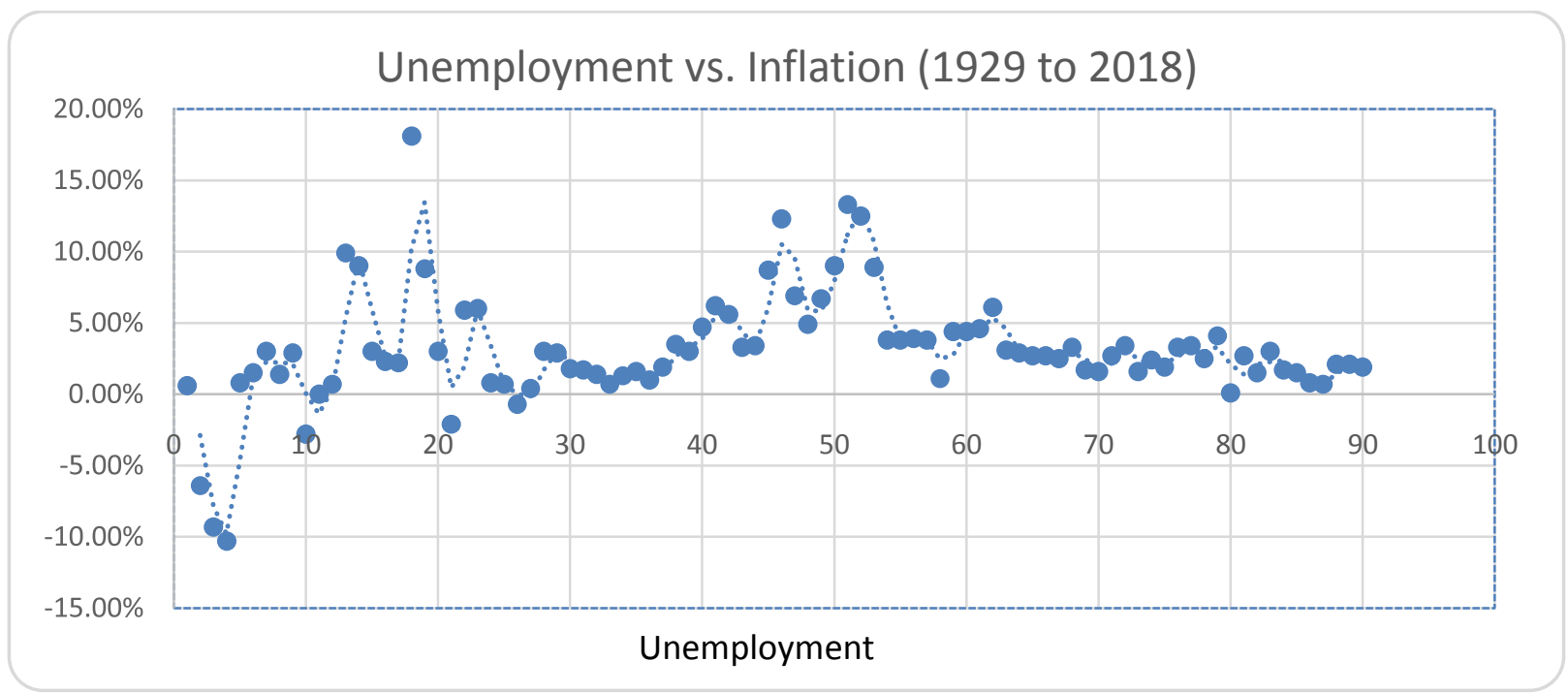

Figure 4. Scatter diagram for unemployment and inflation from 1929 to 2018 for US economy

In Figure 4, the moving averages with the 2-period for the data gathered for unemployment and inflation from 1929 to 2018 for US economy provides the trend line as provided above for the data updated in 2019 (Amado, 2019). However, to the contrary, economists argue that the curve does not agree with the phenomenon that the Phillips curve describes, which is a negative trade-off between inflation and unemployment. Economists have been recently debating on whether the curve has entirely disappeared in the US and Europe or rather some hidden factors have reshaped the theories associated with the Phillips curve.

This data has been analyzed using an independent group t-test (occasionally called an independent samples t-test or parallel test).It shows that there is a strong tendency towards statistical significant, with a value of 0.051 , for the data gathered from 1992 to 2018 that inflation and interest rates are associated. Figure 5 provides the corresponding t-test output when ascertaining the association of inflation and interest rates performed using SAS statistical software. 


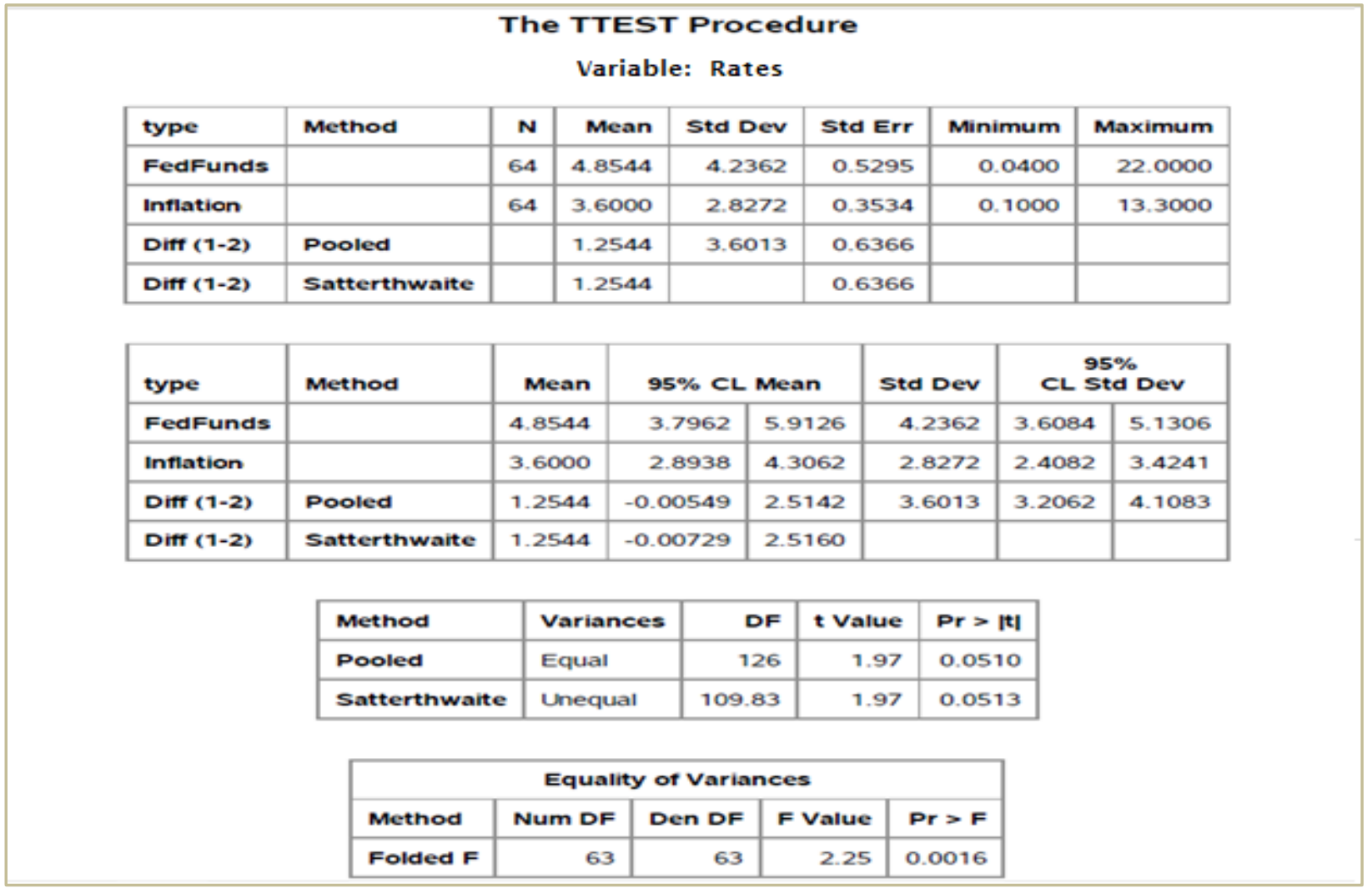

Figure 5.T-test output for the association of inflation and interest rates

The distributions of both Federal Funds rates and inflation are right-skewed. Assumptions for the normality have been narrowly satisfied according to Figure 6. However, the t-test is designated as robust with respect to the assumption of normality. Over the course of the past eight decades (1929-2018), the US economy took turbulent shocks multiple times such as recession, wars, and droughts, which caused the interest rates and inflation to change their trajectory drastically, thus making this an unworthy comparison.

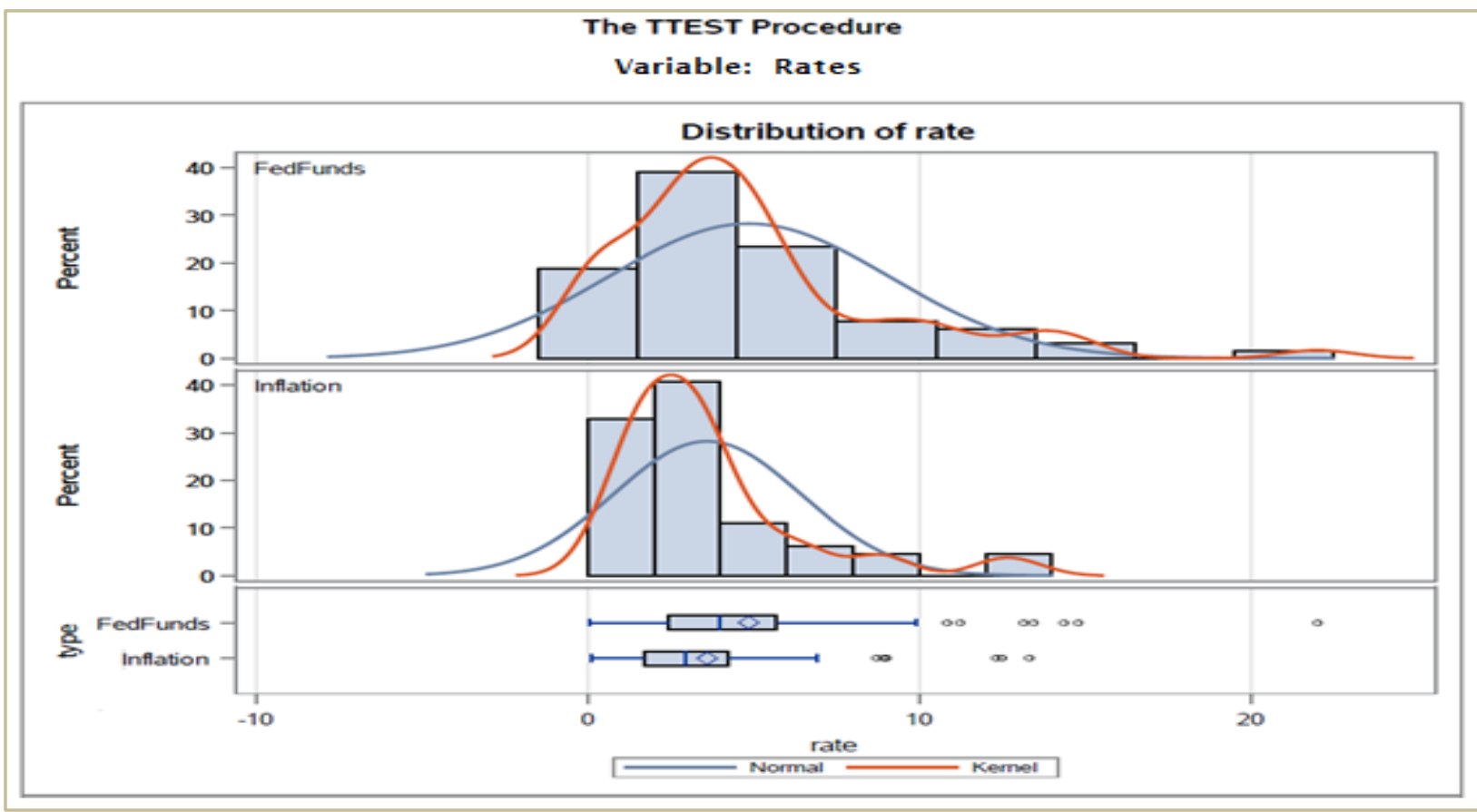

Figure 6. Distribution of fed funds rate vs. year close inflation 


\section{Free Trade Zones}

Free Trade Zones (FTZ) are the outsourcing equivalent for industrial facilities. An FTZ is an isolated area, established outside the custom supervision of a particular country but within its geographical boundaries. It is provided with warehouse and storage facilities, as incentives for logistic and other manufacturer facilities, usually located close to a port of entry, or an airport, and a harbor while having an easy access to all modes of transportation. These enterprises enjoy low labor cost, cooperative taxes and duties, and in particular, exemptions from no-value added tax. Individual countries may decide on other trade policies and governing regularities within their own policies for their business regularities. The manufacturing process allows firms to provide amicable free trade conditions and a liberal regulatory that could have a differential impact on industries in the development process of good and services (Lu, 2014). This also supports the domestic products and helps to sustain a low inflation rate, thus benefiting the consumers at large.

Through FTZ, the goods are value-added for exportation at a competitive cost when the products cannot be competitive in their country's market. It is argued that the countries hosting these facilities will have the advantages from the employability of its people, generating a skillful labor force, opportunities for locals, and additional income from taxation. The tariff has been levied to obstruct fair trade practices and to stabilize the prices of manufacturing goods. These tariffs prevent importation of product and promote goods and services from their countries. Some incentives are provided for farmers to lower the prices of the goods. A fair trade practice for some could lead to an unfair practice for others. Other factors seem to advance long-term migration processes on a global level because of globalization.

\section{Effects of Globalization}

Multifaceted globalization and its unwanted consequences can hurt countries in their economic outlooks. The first US President, George Washington, stated that the US should not meddle in the affairs of the international world and of other countries. However, to dominate in the world stage, it should show the dominance in trade, politics, military, contributing to a larger share in the world market. Understanding and historical events have shown that risk and market uncertainties (volatilities) have significantly impacted the rate of interest (Greenspan. 2004). Globalization is presently considered from a specific economic aspect, but such an important phenomenon must be studied from other viewpoints for a more complete picture (Schlamberger, 2017). It is also argued that globalization can be factored into inflation (Bean, 2006).

Recent empirical work on globalization and inflation analyzes multicounty data sets in panel and/or cross-section frameworks and reaches inconclusive results. Additionally, the inverse association between trade or financial globalization and inflation cannot be ruled out under all circumstances (Kim, Lin, \& Wu, 2016). The present trend toward globalization of financial markets has underwritten huge capital flows to Turkey, Mexico, economies in Southeast Asia, and elsewhere (Ozatay, 1997). A fair question is whether the private capital markets contributed to supply finance to developing countries to be reliable in the end (Taylor, 1997). Kilpatrick in 2001 asserted that, "without empirical guidance, policymakers were willing for the economy to grow above potential with a concomitant decline in the unemployment rate until visible signs of inflation (wage or price) appeared. Moreover, to be certain that inflation would rise, as well as to demonstrate the "symmetric" character of the inflation target, the Federal Open Market Committee (FOMC) intended to err on the side of allowing inflation to overshoot." FOMC guides the level of primary and, by far, the most flexible and actively used instrument of monetary policy that include open market operations that has implication to effect changes in reserves.

\section{Outsourcing and US Industries}

Economic conditions favor outsourcing as the enterprises' constant motivation is to generate profits. Outsourcing seems to be profitable in dollars and cents terms. Consequently, at the time being, customer services departments for most US product outlets are located outside the US or other parts of the world for the products marketed in the US. For example, Hyderabad, India has established call centers for most US companies. Every time there has been a need for consultations, product exchanges, and services for these products, someone on the other end answers these calls. If someone is not accustomed to their cultures, geographical locations, time differences, and language it could direct them incorrectly. For example, a person at one-end of the conversation could be calling late at night. Thus, causing inconvenience, frustration, and most importantly additional expenses for the consumer. This could damage the reputation and image of the manufacturers causing long-term losses for them. When these services are sought, their qualification for the nature of employment is not verified, contrasted against similar employment opportunities in the US, where their qualification, custom relation, courtesy, quick thinking, and problem solving capabilities are required. Usually, these workers were asked to solve the problems for its competition and final resolution. For live entertainment events such as sports (Olympic, tennis tournament), service crew's participation would undergo similar time changes. We are accustomed to watching live sport events as they happen in other parts of the world around midnight or early in the morning. 
Exchange rate plays a vital role in a country's level of trade, which is critical to most, or all, free market economies in the world. Its variance is persistent and serially correlated long-term economic growth providing a relationship between interest rate, inflation rate and exchange rate volatility in Malaysia covering the period between 1999 and 2009 (Asari et al., 2011).A study has been done on empirical analysis to find out the role of trade openness, inflation, imports, exports, real exchange rate and foreign direct investment in enhancing economic growth in Pakistan for the period 1980 to 2011 (Bibi, 2014). This study concluded that a similar effect would take place on trade imbalance and the stock market, as some have already asserted.

It appears that all stock market indices continue to increase on average whilst the trade imbalance remains steady in recent years. This is in fact true for all three major indices, S\&P 500 (Standard \& Poor's 500), DOW (Dow Jones Industrial), and NASDAQ (Nasdaq Stock Market) since 9/11. On the other hand, the difference between exports and imports has caused a significant effect leading to the trade imbalance. Trade balance is usually the result of production and varies by country (sometimes due to bilateral trade balances). Commodities and productions generally cause imbalances in trade. A surplus in the balance of trade occurs when exports exceed imports and a deficit occurs when imports gain the upper hand. In this presentation, this anomaly is presented with some examples.

Table1. Inflation and Unemployment Rate for few developed, developing, and underdeveloped countries

\begin{tabular}{|l|l|l|l|}
\hline Status & Countries & Inflation Rate in 2018 & Unemployment Rate in 2018 \\
\hline Developed & United States & $1.90 \%$ & $3.90 \%$ \\
& Sweden & $2.00 \%$ & $6.00 \%$ \\
\hline & Germany & $1.60 \%$ & $3.30 \%$ \\
\hline Developing & Israel & $0.80 \%$ & $4.20 \%$ \\
\hline & Russia & $4.30 \%$ & $4.80 \%$ \\
\hline & Brazil & $3.75 \%$ & $11.60 \%$ \\
\hline \multirow{2}{*}{ Under Developed } & Argentina & $47.10 \%$ & $9.00 \%$ \\
\hline & Ethiopia & $11.44 \%$ & $23.10 \%$ \\
\hline & Myanmar & $10.40 \%$ & $19.10 \%$ \\
\hline & Afghanistan & $6.84 \%$ & $1.60 \%$ \\
\cline { 3 - 5 } & Haiti & $0.80 \%$ & $8.80 \%$ \\
\hline
\end{tabular}

Source: https://tradingeconomics.com/analytics/indicators.aspx

Table 1 gives a glimpse of how inflation and unemployment rates for a few developed, developing, and underdeveloped countries bring the point that no country in the world is immune from the realities of inflation regardless of it being a developed, developing, and underdeveloped.

\section{Terrorism and Associated Threats}

Major disasters can contribute to inflation. Terrorism is defined, according to the US Department of Defense as, "the unlawful use of -- or threatened use of -- force or violence against individuals or property to coerce or intimidate governments or societies, often to achieve political, religious, or ideological objectives" (Schmid, 2004). The FBI defines terrorism as "the unlawful use of force or violence against persons or property to intimidate or coerce a government, the civilian population, or any segment thereof, in furtherance of political or social objectives" (Weinberg, Pedahzur, \& Hirsch-Hoefler, 2004). However, from (Janse, 2016), it reads that the systematic use of violence to achieve political ends is not new - for instance, it was employed by pro- and anti-slavery fanatics in Kansas before the American Civil War, by anarchists in Tsarist Russia, and by the Black Hand organization in the Balkan Islands before World War I. In recent decades, it has become a common tactic among a wide variety of groups, from independence movements to the secret services of various countries. Random bombings, shootings and/or 'disappearances' - and the fear and panic they provoke - put pressure on governments, proving that they are unable to protect their populations, or can be used by dictatorships to frighten their people into submission and obedience. 
Additionally, the globalization and international terrorism are conceivably the leading threats to long-term stability in the twenty-first century in the world (Cronin, 2002). Free flow of information, persons, goods, money, and technology seem to be the driving force for globalization. When this flow leads to an imbalance, and causes dire economic situations, it may cause terrorism to flourish. The monetary aggregates were mainly due to structural changes in the economy resulting in the nature of the pace of disinflation, consistent with its other objectives of sustainable high international and domestic economic developments. Furthermore, the question can be asked how effective the implementation of inflation targeting has been in South Africa. Unfortunately, there is only a relatively short period over which the performance of inflation can be assessed. In 2002, an inflation target was specified based on an average annual rate of increase was relatively low (der Merwe, 2004).

\section{Migration vs. Trade}

Inflation can have an undesirable consequence on a country's migration rate. The effect is noteworthy. An increase in the inflation rate of a country, leads to a small decrease in migration rate as in the Netherlands, for example. Robustness estimations of inflation can be a sign that an economy is thriving. When an economy grows, the push factors for migrating have less effect than expected. The incentive to leave the country decreases the progress (Jut, 2015). Trade and migration have largely contributed to the globalization as well. The international trade agreements such as North American Free Trade Association (NAFTA), Central American Trade Association (CAFTA), and other trade zones opportunities like, Macedonia, the United Arab Emirates, Egypt, and Saudi Arabia have offered free-trade facilities in the recent past to facilitate these aspects of globalization.

The migration and trade between NAFTA and CAFTA countries and can shed some light to decide as to how each country has benefited from their respective population migration. The data assembled using the table 10 of (Kilpatrick, 2001). An estimated $10 \%$ of unauthorized population transfer is assumed since year 2000 for the following table in addition to migration resulted from visas issued for temporary workers, transferees, exchange visitors, permanent migration, and US foreign-born population. This shows the effects of globalization in terms of migration.

Table 2. Aggregate Migration and Trade between NAFTA and CAFTA countries, 2004-2005

\begin{tabular}{|l|l|l|l|l|}
\hline Country & $\begin{array}{l}\text { Transfer of Shared } \\
\text { Population (2006) }\end{array}$ & $\begin{array}{l}\text { Remittances in 2005 } \\
\text { (in millions) }\end{array}$ & $\begin{array}{l}\text { Shared Imports } \\
\text { from US 2004 }\end{array}$ & $\begin{array}{l}\text { Shared Exports to } \\
\text { US 2004 }\end{array}$ \\
\hline Canada & $3 \%$ & - & $58.7 \%$ & $84.5 \%$ \\
\hline Costa Rica & $1 \%$ & $\$ 362$ & $44.9 \%$ & $44.4 \%$ \\
\hline Dominican Rep. & $9 \%$ & $\$ 2,682$ & $44.8 \%$ & $40.2 \%$ \\
\hline El Salvador & $26 \%$ & $\$ 2,830$ & $31.2 \%$ & $23.1 \%$ \\
\hline Guatemala & $5 \%$ & $\$ 2,993$ & $40.9 \%$ & $29.4 \%$ \\
\hline Honduras & $5 \%$ & $\$ 1,763$ & $40.0 \%$ & $41.9 \%$ \\
\hline Mexico & $17 \%$ & $\$ 20,034$ & $56.6 \%$ & $88.6 \%$ \\
\hline Nicaragua & $3 \%$ & $\$ 850$ & $22.3 \%$ & $36.1 \%$ \\
\hline
\end{tabular}

\section{Measurements of Globalization}

Globalization is presently considered in the context of economic interests by countries. Globalization seems to benefit everyone; however, it is clear there are some unwanted consequences from its mere existence. There are areas other than economics that globalization has influenced and affected. There is evidence to back up these claims (Friedman, 2006). For example, trade and culture. Governmental organizations such as UN, IMF, WTO, and WB and private organizations, IGAS and nongovernmental organizations have contributed to globalization largely. Some measures are needed to look into the various impact of globalization. The manuscript (as of end of 2003), Prasad et al., (2003) attempted to come up with parameters that measure globalization. The degree of globalization has been discussed therein. There are measurable and non-measurable parameters for globalization. Culture, etc. are considered nonmeasurable, whereas defense and immigration are measurable (Abrams \& Hamilton, 2006).

Does poverty reflect inflation? Inflation affects the poor very badly, and worse, it affects them permanently and for generations. Particularly for the poor, inflation forces them to spend almost their entire wealth for every day necessities of survival such as purchasing food, clothing and shelter, in that order of magnitude. There are situations in which it could have offset their impact on long-term interest rates, and how sustainable they are. It is not surprising that many policymakers continue to remain optimistic about the sustainability of their respective economies stemming from the permanent factors underlying dynamics of G-7 real interest rates in the "new economy" (Hauner\& SKumar, 2006). Feldstein (1983) argued that there are effects of corporate and personal income taxation on the relationship between interest rates and inflation, which have previously been ignored by past economists, namely Fisher and Tobin. He posits that the effect taxation has is substantial in the relation of interest rates to the rate of inflation. 
His major claim in the paper is the "importance of revising the definition of taxable income and expenses to neutralize the effects of inflation". In this case, the effects of inflation pertain to the idea that inflation causes a loss in "real" interest gain if inflation exceeds interest rates.

\section{Conclusions}

This paper has successfully, through discussion and statistical analysis, shown that interest rates have influence on inflation rates. It needs to be said that manipulation of interest rates is not enough to curb inflation; there are other remedies that can be employed to mitigate the effect of inflation to the economic development of a nation. The interest rates and inflation have been statistically compared to verify that there is an association between them. However, everything has its own limitations, merits, and other variety of factors, as provided in the paper, that overwhelmingly influence the inflation rates. It can be someone's imagination, most part and cannot do anything about it unless finding the ways to reduce their effect on the economy beyond any impact of economic catastrophes and calamity.

\section{Acknowledgements}

The second author has undertaken preliminary work of this research project during the coursework of MATH 4395490Senior Mathematics Project completed in Summer-II 2019 from July 8 to August 8, 2019 at Texas A\&M International University (TAMIU), Laredo, Texas. The authors would like to thank Manuel Fernandez and Paola M. Segovia, who were immensely involved in the preliminary draft of this paper.

\section{References}

Abrams, Spencer and Lee H. Hamilton (2006). Immigration and America's Future: A New Chapter, Report of the Independent Task Force on Immigration and America's Future, Co-Chairs-Spencer Abrams and Lee H. Hamilton, September 2006, Migration Policy Institute

Akgay, O. Cevdet; C. EmreAlper, and SuleymanOzmucur, (2018). Budget Deficit, Inflation and Debt Sustainability: Evidence from Turkey, 1970-2000. In Inflation and Disinflation in Turkey, pp. 83-102. Routledge.

Amado, Kimberly (2019). Unemployment Rate by Year Since 1929 Compared to Inflation and GDP, Economy Stats Unemployment, U.S. Unemployment Rate History, June 25, 2019, https://www.thebalance.com/unemployment-rate-by-year-3305506

Asari, FadliFizari Abu Hassan, NurulSyuhadaBaharuddin, NurmadihahJusoh, Zuraida Mohamad, NorazidahShamsudin, and KamaruzamanJusoff (2011). A Vector Error Correction Model (VECM) Approach in Explaining the Relationship Between Interest Rate and Inflation Towards Exchange Rate Volatility in Malaysia, World Applied Sciences Journal 12 (3), pp. 49-56, 2011. 80, 2011.

Ayanian, Robert (1983). Expectations, Taxes, and Interest: The Search for the Darby Effect. The American Economic Review, vol. 73, no. 4, 1983, pp. 762-765. JSTOR, www.jstor.org/stable/1816574.

Bean, Charles Richard (2006). Globalization and Inflation. Bank of England Quarterly Bulletin, Winter 2006. Available at SSRN: https://ssrn.com/abstract=950977

Bibi, Sadia (2014). Impact of Trade Openness, FDI, Exchange Rate and Inflation on Economic Growth: A Case Study of Pakistan, International Journal of Accounting and Financial Reporting, 4(2): pp. 236-57

Blanchard, Olivier J. (1984). Current and anticipated deficits, interest rates and economic activity, European Economic Review, Elsevier, vol. 25(1), pp. 7-27, June.

Browning, Edgar K. and Browning, Jacquelene M. (1986). Microeconomic Theory and Applications, Second Edition, Little Brown \& Company, 1986

Chisari, Omar, Fanelli, José Maria and Frenkel, Roberto. (1996). Argentina: Growth Resumption, Sustainability, and Environment. World Development. 24, pp. 227-240. 10.1016/0305-750X (95)00133-W.

Cochrane, John H., and Monika Piazzesi (2002). The Fed and Interest Rates: A High-Frequency Identification. The American Economic Review, vol. 92, no. 2, 2002, pp. 90-95. JSTOR, www.jstor.org/stable/3083383.

Cronin, Audrey Kurth (2002). Behind the Curve, Globalization and International Terrorism, International Security, Vol. 27.3 (2002/03) pp. 30-58. Retrieved from

http://muse.jhu.edu/journals/international_security/v027/27.3cronin.html

Crowder, William J., and Dennis L. Hoffman (1996). The Long-Run Relationship between Nominal Interest Rates and Inflation: The Fisher Equation Revisited. Journal of Money, Credit and Banking, vol. 28, no. 1, 1996, pp. 102118. JSTOR, www.jstor.org/stable/2077969.

Espinoza, Lorna P., Goonatilake, Rohitha, \&Herath, Susantha (2018). Managing the Three Pillars of the Economy for Sustainable Growth. Journal of Economics and Development Studies. 6. 10.15640/jeds.v6n4a1.

Feldstein, Martin (1983). Inflation, Income Taxes, and the Rate of Interest: A Theoretical Analysis. National Bureau of Economic Research. University of Chicago Press 1983. 
Friedman, Benjamin M. (2006). The Moral Consequences of Economic Growth, Society, January 2006, Volume 43, Issue 2, pp 15-22 43: 15. https://doi.org/10.1007/BF02687365

Gandolfi, Arthur E. (1982). Inflation, Taxation, and Interest Rates. The Journal of Finance, vol. 37, no. 3, 1982, pp. 797-807, www.jstor.org/stable/2327709.

Greenspan, Alan. (2004). Risk and Uncertainty in Monetary Policy. American Economic Review, 94 (2): pp. 33-40. DOI: 10.1257/0002828041301551

Hauner, David and S. Kumar, Manmohan. (2006). Fiscal Policy and Interest Rates--How Sustainable Is the "New Economy"? International Monetary Fund, IMF Working Papers. 06. 10.5089/9781451863727.001.

Higgins, Robert C. (1981). Sustainable Growth under Inflation, Financial Management, Autumn, 1981, pp. 36-40.

Ireland, Peter N. (2000). Interest Rates, Inflation, and Federal Reserve Policy since 1980. Journal of Money, Credit and Banking, vol. 32, no. 3, 2000, pp. 417-434. JSTOR, www.jstor.org/stable/2601173.

Janse, Maartje (2016). Anti-Societies Are Now All the Rage: Jokes, Criticism, and Violence in Response to the Transformation of American Reform, 1825-1835, Journal of the Early Republic, University of Pennsylvania Press, Volume 36, Number 2, Summer 2016, pp. 247-282

Jut, Anneke (2015). The Effect of Trade on Migration to the Netherlands, Erasmus University Rotterdam, Master Thesis for Master Economics of Markets, Organizations and Policy, Rotterdam, 18 February 2015

Kandel, Shmuel, Aharon R. Ofer and OdedSarig (1996). Real Interest Rates and Inflation: An Ex-Ante Empirical Analysis. The Journal of Finance, vol. 51, no. 1, 1996, pp. 205-225. JSTOR, www.jstor.org/stable/2329307.

Kellison, Stephen G. (1991). The Theory of Interest, Second Edition, Irwin/McGraw-Hill, a division of the McGrawHill Companies

Khumalo, Lindiwe Catherine; Emmanuel Mutambara and AkwesiAssensoh-Kodua (2017). Relationship Between Inflation and Interest Rates in Swaziland Revisited. Banks and Bank Systems, 12(4), pp. 218-226. doi:10.21511/bbs.12 (4-1).2017.10

Kilpatrick, Andrew J., (2001). Transparent Frameworks, Fiscal Rules and Policy-Making under Uncertainty (February 1, 2001). Available at SSRN: https://ssrn.com/abstract=2094468 or http://dx.doi.org/10.2139/ssrn.2094468

Kim, Dong-Hyeon; Shu-Chin Lin, and Yi-Chen Wu (2016). Globalization and Inflation: New Panel Evidence: Macroeconomic Dynamics, 20, 2016, pp. 1-26. Printed in the United States of America. doi:10.1017/S1365100514000510

Leuthold, Steven C. (1981). Interest Rates, Inflation and Deflation, Financial Analysts Journal, vol. 37, no. 1, 1981, pp. 28-41. JSTOR, www.jstor.org/stable/4478418.

Levi, Maurice D., and John H. Makin (1978). Anticipated Inflation and Interest Rates: Further Interpretation of Findings on the Fisher Equation. The American Economic Review, vol. 68, no. 5, 1978, pp. 801-812. JSTOR, www.jstor.org/stable/1811313.

Levine, David A. (1981). Inflation and Interest Rates. Financial Analysts Journal, vol. 37, no. 3, 1981, pp. 77-78. JSTOR, www.jstor.org/stable/4478456.

Ley, Eduardo (2009). Fiscal (and External) Sustainability, The World Bank, 28. February 2009

Lu, Xia (2014). The Development Process, Functional Evaluation, and Implications of World Free Trade Zones. World Review of Political Economy, vol. 5, no. 3, 2014, pp. 359-371. JSTOR, www.jstor.org/stable/10.13169/worlrevipoliecon.5.3.0359

Online at http://mpra.ub.uni-muenchen.de/13693/ MPRA Paper No. 13693, posted on March 2, 2009 00:05 UTC

Ozatay, Fatih, (1997). Sustainability of Fiscal Deficits, Monetary Policy, and Inflation Stabilization: The Case of Turkey, Journal of Policy Modeling, Elsevier, vol. 19(6), pp. 661-681, December.

Prasad, Eswar S., Kenneth Rogoff, Shang-Jin Wei, and M. AyhanKose (2003). Effects of Financial Globalization on Developing Countries: Some Empirical Evidence, Occasional Paper, International Monetary Fund, Washington DC, 2003

Schlamberger, Niko (2017). Globalization - What, Why, and How to Measure. Statistical Office of the Republic of Slovenia, 2017. Retrieved from:

http://www.czso.cz/sif/conference2004.nsf/i/9F4C2C0FD235A443C1256EDD0031562A/\$File/Schlamberger. pdf

Schmid, Alex P. (2004). Frameworks for Conceptualizing Terrorism, Terrorism and Political Violence, 16:2, pp. 197221, DOI: 10.1080/09546550490483134

Sernau, Scott (2006). WORLD Apart, Social Inequality in a Global Economy, Second Edition, 2006, Pine Forge Press, Thousand Oaks, California

Taylor, Lance (1997). Editorial: The Revival of the Liberal Creed - the IMF and the World Bank in a Globalized Economy, World Development, Vol. 25, No. 2, pp. 145-152, 1997 Copyright 01997 Elsevier Science Ltd Printed in Great Britain. Elsevier Science Ltd. 
Van der Merwe, EJ (2004). Inflation Targeting in South Africa, Occasional Paper No 19, July 2004, South African Reserve Bank

Van Wijnbergen, Sweder (1990). External Debt, Inflation, and the Public Sector: Towards Fiscal Policy for Sustainable Growth, The World Bank Economic Review, vol.3, No.3, pp. 297- 320

Weinberg, Leonard; Ami Pedahzur and Sivan Hirsch-Hoefler (2004). The Challenges of Conceptualizing Terrorism, Terrorism and Political Violence, 16:4, pp. 777-794, DOI: 10.1080/095465590899768 